\title{
APPEALABILITY OF JUDGIIENTS ENTERED PURSUANT TO REMITTITURS IN FEDERAL COURTS
}

The practice of allowing a trial judge to condition his refusal of a defendant's motion for a new trial upon the plaintiff's acceptance of a reduction in damages, known as a remittitur, has had a long, if soinewhat uneven, history in the federal court system. ${ }^{1}$ In particular, this mechamism for imposing the judge's will upon the determination of damages in a civil trial has been criticized ${ }^{2}$ in light of the seventh amendment's seemingly categorical inandate that

[i]n suits at common law, where the value in controversy shall exceed twenty dollars, the right of trial by jury shall be preserved, and no fact tried to a jury, shall be otherwise re-examined in any Court of the United States, than according to the rules of the common law. ${ }^{3}$

A remittitur order places the plaintiff in a quandary: if he refuses to remit part of his verdict and subunits to a new trial, ${ }^{4}$ there is a possibility that he will receive a lower damage award in the second trial, and a certainty that he will imcur further expenses in the later proceeding; alternatively, he may file the remittitur, giving up that part of his verdict which the trial judge considers unreasonable, but avoiding the new trial. Under the traditional rule, a plaintiff who elects the latter course is foreclosed from bringing any appeal based upon the ensuing judgment. ${ }^{5}$ In a hine of cases beginning with Delta Engineering Co. $v$. Scott ${ }^{6}$ and continuing most recently through Bonura v. Sea Land Serv-

1. See Dimick v. Schiedt, 293 U.S. 474, 483-84 (1935).

2. Id. at 482-84. See text accompanying notes 57-69 infra.

3. U.S. CoNST. amend. VII. Rernittiturs were approved in Arkansas Valley Land \& Cattle Co. v. Mann, 130 U.S. 69 (1889).

4. An order granting a new trial usually is not appealable, since it lacks the fimality required by 28 U.S.C. $\$ 1291$ (1970). Such an order may be reviewed after a judgment has been eutered at the subsequent trial; however, the complaining litigant must reserve his appeal until after the second trial. See, e.g., Dillard Dep't Stores, Inc. v. Fidelity Union Life Ins. Co., 508 F.2d 331 (5th Cir. 1975); cf. Montgomery Ward \& Co. v. Duncan, 311 U.S. 243, 254 (1940). See generally 6A J. MOORE, FEDERAI PRACTICE II 59.15[1], at 59-273 to 59-275 (2d ed. 1974); 11 C. WRIGHT \& A. MILLER, FEDERAL Practice ANd Procedure: Crvil \$ 2818, at 113-17 (1973).

5. See, e.g., Casko v. Elgin, J. \& E. Ry., 361 F.2d 748, 751 (7th Cir. 1966); Movible Offshore Co. v. Ousley, 346 F.2d 870, 875 (5th Cir. 1965); S. Birch \& Sons v. Martin, 244 F.2d 556, 562 (9th Cir.), cert. denied, 355 U.S. 837 (1957). Movible Offshore Co. v. Ousley, a decision following the traditional rule where the remittitur is not protested at the time it is filed, indicates the essential quality of the protest itself.

6. 322 F.2d 11 (5th Cir. 1963). 
ice, Inc., ${ }^{7}$ the Fifth Circuit has allowed plaintiffs who are put to the choice of a reduction in damages or the risk and expense of a new trial to accept the remittitur "under protest," i.e., with reservation of a right to appeal. These decisions allow a plaintiff to take judgment for the reduced amount and then to claim on appeal that the trial judge's remittitur order was erroneous. ${ }^{8}$ The Sixth Circuit has also allowed a party to appeal after accepting a remittitur under protest. ${ }^{9}$ However, while the Fifth Circuit has adopted the procedure by judicial choice, the Sixth Circuit has reasoned that the matter inust be governed by state law. ${ }^{10}$

This Note will examine the legal and practical considerations underlying the decisions of the federal courts on the use of the "under protest" remittitur. ${ }^{11}$ Three basic issues arise from the decisions: first, whether a federal court must conform its practice as to appeals by remitting parties to that of the state in which it sits; second, assuming the absence of such a choice of law rule, whether Supreme Court precedent ${ }^{12}$ forecloses adoption of the under protest remittitur by federal courts; and, finally, the degree to which adoption of the "under protest" rule would affect the distribution of the workload between district courts and courts of appeals.

\section{Application of the "Under Protest" Rule as a QUESTION OF STATE LAW}

The Supreme Court case most directly on point for the question of whether a state practice which is solicitous of juries ${ }^{13}$ must be applied in federal courts in the face of a contrary federal practice is Herron $v$. Southern Pacific Co. ${ }^{14}$ Herron involved the issue of whether the Rules of

7. 505 F.2d 665 (5th Cir. 1974).

8. Wiggs v. Courshon, 485 F.2d 1281, 1283 (5th Cir. 1973).

9. Mooney v. Henderson Portion Pack Co., 334 F.2d 7 (6th Cir. 1964).

10. Id. at 8-9. The Second Circuit has recorded conflicting precedents. Compare Burris v. American Chicle Co., 120 F.2d 218, 223 (2d Cir. 1941), with Mattox v. News Syndicate Co., 176 F.2d 897, 904 (2d Cir. 1949). The Second Circuit discussed the "under protest" rule in a recent case without deciding whether to apply the rule. Reinertsen v. George W. Rogers Constr. Corp., No. 564 (2d Cir., July 3, 1975).

11. For a discussion of a related issue in a state-court context, see Note, Civil Procedure-Remittitur-Remitting Parties Right to Cross-Appeal, 49 N.C.L. REv. 141 (1970).

12. Woodworth v. Chesbrough, 244 U.S. 79, 80-81 (1917); Koenigsberger v. Richmond Silver Mining Co., 158 U.S. 41, 52 (1895). See text accompanying notes 4148 infra.

13. See text accompanying note 73 infra.

14. 283 U.S. 91 (1931). 
Decision Act ${ }^{15}$ mandated the application in a federal court sitting in Arizona of article 15, section 5 of the Arizona Constitution, which provided that "[t]he defense of contributory negligence sliall, in all cases whatsoever, be a question of fact and sliall, at all times, be left to the jury." 10

The specific question presented was whether a federal trial judge might direct a verdict for the defendants on the ground that the plaintiffs were contributorily negligent. ${ }^{17}$ The Supreme Court answered the question in the affirmative, holding that "the controlling principle governing the decision of the present question is that state laws cannot alter the essential character or function of a federal court."18 It would seem that the appealability in federal court of a remittitur filed "under protest" can be no more an issue for application of state rules than was the power of a federal judge to direct a verdict in Herron. Application of the Arizona rule in Herron would liave "alter[ed] the essential character ... of a federal court"; ${ }^{10}$ application of state "under protest" procedure in the absence of an analogous federal practice would seem to alter the very jurisdiction of a federal court of appeals.

Nevertheless, the Sixth Circuit Court of Appeals lield in Mooney $v$. Henderson Portion Pack Co. ${ }^{20}$ that a Tennessee statute ${ }^{21}$ allowing appeals from judgment entered pursuant to "under protest" remittiturs

15. 28 U.S.C. $\S 1652$ (1970). "State laws as rules of decision. The laws of the several states, except where the Constitution or treaties of the United States or Acts of Congress otherwise require or provide, shall be regarded as rules of decision in civil actions in the courts of the United States, in cases where they apply."

16. This constitutional provision had been interpreted by the Arizona Supreme Court to render the jury's verdict conclusive upon the court on the contributory negligence issue. Inspiration Consol. Copper Co. v. Conwell, 21 Ariz. 480, 486-88, 190 P. 88, 90-91 (1920).

17. 283 U.S. at $92-93$.

18. Id. at 94 .

19. Id.

20. 334 F.2d 7 (6th Cir. 1964). Mooney was recently reaffirmed in Manning v. Altec, Inc., 488 F.2d 127, 130-31 (6th Cir. 1973).

21. The Tennessee statute applied in Mooney provides a clear example of the operation of the "under protest" rule:

Reversal on protested remittitur.-In all jury trials had in civil actions, after the verdict has been rendered, and on motion for a new trial, when the trial judge is of the opinion that the verdict in favor of a party should be reduced, and a remittitur is suggested by him on that account, with the proviso that in case the party in whose favor the verdict has been rendered refuses to make the remittitur a new trial will be awarded, the party in whose favor such verdict has been rendered may make such remittitur under protest, and appeal from the action of the trial judge to the Court of Appeals; and if, in the opinion of said Court of Appeals, the verdict of the jury should not have been reduced, but that the judgment of the trial judge is correct in other respects, the case shall be reversed to that extent, and judgment shall be rendered in the Court of Appeals for the full amount originally awarded by the jury in the trial court. TENN. CODE ANN. \$ 27-118 (1955). 
must govern the practice of a federal district court sitting in Tennessee, as well as that of the court of appeals supervising that district. ${ }^{22}$ In a cryptic per curiam opinion, the court simply cited two Supreme Court cases, Erie Railroad v. Tompkins ${ }^{23}$ and Guaranty Trust Co. v. York, ${ }^{24}$ for that proposition, but gave no explanation of the way in which those decisions mandate such a result.

In fact, close examination of Erie leads inescapably to the conclusion that Mooney represents a misapplication of that decision to the remittitur under protest problem. Erie itself, while far-reaching in its implications, wrought substantial change in the federal courts only insofar as it held that state decisional law was included in the phrase "the laws of the several states" in the Rules of Decision Act. ${ }^{25}$ Even under the prior position of the Supreine Court, ${ }^{26}$ the phrase "the laws of the several states" was universally assumed to include state statutes. ${ }^{27}$ Thus, it would appear that the decision in Herron was unaffected by Erie, a conclusion which is supported by a subsequent Supreme Court opinion. ${ }^{28}$

Guaranty Trust Co. v. York, ${ }^{29}$ the other Supreme Court case cited in Mooney, held that a state's statute of limitations must be applied in federal equity courts sitting in that state. ${ }^{30}$ The Court based its decision upon what it termed the "policy" embodied in Erie: "that for the same transaction the accident of a suit by a non-resident litigant in a federal court instead of in a State court a block away should not lead to a substantially different result." 31 Hence, the Sixth Circuit's reliance on Guaranty Trust in deciding Mooney nust have been predicated upon a behief that Guaranty Trust's "outconie determination" test is still the appropriate means of solving choice of law problenis in federal-state law conflicts, and, further, that the Tennessee "under protest" statute is in fact "outcome-determinative."

Both of these conclusions seen doubtful in the light of Supreme Court cases decided after Guaranty Trust. In Byrd v. Blue Ridge Rural

22. 334 F.2d at $8-9$.

23. 304 U.S. 64 (1938).

24. 326 U.S. 99 (1945).

25. 28 U.S.C. $\S 1652$ (1970). See note 15 supra.

26. Swift v. Tyson, 41 U.S. (16 Pet.) 1, 18 (1842), overruled, Erie R.R. v. Tompkins, 304 U.S. 64, 77-78 (1934).

27. Byrd v. Blue Ridge Rural Elec. Cooperative, Inc., 356 U.S. 525, 539 (1958).

28. Id. at 538-39.

29. 326 U.S. 99 (1945).

30. Id. at 101, 110-12.

31. Id. at 109. 
Electric Cooperative, Inc. ${ }^{32}$ the Court held that a South Carolina Supreme Court decision mandating the determination of a factual issue by the trial judge would not be binding upon a federal court in a diversity action, where federal practice dictated the determination of the issue by the jury. ${ }^{33}$ The Court noted that, while "outcome determination" analysis as set out in Guaranty Trust might dictate application of the state rule, "affirmative countervailing considerations" would allow the federal courts to set their own policy as to certain disputed procedural inatters. ${ }^{34}$ According to the Court in Byrd, one such "countervailing consideration" is the "strong federal policy against allowing state rules to disrupt the judge-jury relationship in the federal courts,"35 and Herron was cited by the Court as authority for this strong federal policy. ${ }^{36}$ It would thus seem that under Herron and Byrd, the issue of the appealability of remittiturs filed "under protest" is one for the federal courts to resolve on principles of federal law alone, without constraint from state procedures.

This conclusion is also supported by the most recent in the Erie line of cases, Hanna v. Plumer. ${ }^{37}$ Hanna presented the question of whether a state rule as to service of process should be followed by a federal court in a diversity case, even though that rule conflicted with Federal Rule of Civil Procedure 4(d)(1). The Court held that the federal rule should prevail, stating that the "outcome determination" test set forth in Guaranty Trust was overly strict as applied to procedural matters, inasmuch as every procedural rule is potentially "outcoine determinative" ex post facto. ${ }^{38}$ According to Hanna, the proper test of whether state or federal law should apply in a given case must be framed with "reference to the twin aims of the Erie rule: discouragement of forum-shopping and avoidance of inequitable administration of the laws."30 The impact of nonapplication of the "under protest" rule in federal courts upon either of these aims would seein to be rather minimal; it is unlikely, from a practical point of view, that a plaintiff would choose a state court over a federal court, or vice versa, on the

32. 356 U.S. 525 (1958).

33. Id. at 533-34, 538.

34. Id. at 537 .

35. Id. at 538 .

36. Id. at 538-39.

37. 380 U.S. 460 (1965). The inconsistency of Mooney with Hanna was noted by the Seventh Circuit in Dorin v. Equitable Life Assurance Soc'y of the United States, 382 F.2d 73, 78 (7th Cir. 1967), in which, on highly similar facts, the result reached in Mooney was specifically rejected.

38. 380 U.S. at 468 .

39. Id. 
basis that one but not the other would allow him to appeal directly a remittitur order erroneously issued by the trial judge. ${ }^{40}$

\section{The “Under Protest” Rule and the Supreme Court}

Given that the federal courts are not obligated by Erie and its progeny to follow state practice as to appeals by remitting parties, the inquiry shifts to whether federal appellate courts are bound to traditional practice by authoritative decisions of the Supreme Court. Attempted appeals by remitting parties were involved in two rather old Supreme Court cases, Koenigsberger v. Richmond Silver Mining Co.41 and Woodworth v. Chesbrough. ${ }^{42}$ In Koenigsberger, the plaintiff brought a contract action in a Dakota territorial court, and received a verdict in his favor. The trial court overruled the defendant's motion for a new trial on the grounds of excessiveness of the verdict and newly discovered evidence; the defendant then appealed from the judgment entered on the verdict to the Supreme Court of the Territory. After the docket of the Supreme Territorial Court was transferred to the newly formed Supreme Court of South Dakota, the defendant successfully petitioned for removal of the case to the United States Circuit Court for the District of South Dakota. The Circuit Court heard the appeal and, being satisfied that the damages found by the jury were excessive and that the trial judge had erred in ruling thereon, ordered reversal of the judgment and the grant of a new trial unless the plaintiff agreed to remit half of his original judgment. The plaintiff filed the remittitur; both parties excepted to the circuit court's action and sued out writs of error. The United States Supreme Court held that the plaintiff, by accepting the circuit court's remittitur, had "waived all right to object to the order of the court, of the benefit of which he had availed himself." 43

Woodworth v. Chesbrough ${ }^{44}$ is more directly applicable to Fifth Circuit practice in that the plaintiff in Woodworth attempted to utilize a form of the "under protest" rule. Chesbrough had appealed froin the trial court's denial of his motion for a new trial on the ground of excessive damages. The Court of Appeals for the Sixth Circuit agreed with the defendant's contentions, but affirmed the trial court's judgment after the plamtiff agreed to file a remittitur. The proffered remittitur contamed a clause stating that plaintiff had agreed to the reduction in damages

40. Cf. 11 C. WRIGHT \& A. MrlLER, supra note 4, \& 2802, at 31 (1973).

41. 158 U.S. 41 (1895).

42. 244 U.S. 79 (1917).

43. 158 U.S. at 52 .

44. 244 U.S. 79 (1917). 
for the sole purpose of obtaining the entry of a final judgement herein, and of securing the affirmance of that part of the judgement which is not so remitted, and is intended to be without prejudice to plaintiff in any cross proceeding hereafter prosecuted by him before the Supreme Court of the United States . ...45

The Court of Appeals approved the remission, stating however that "such approval is not to be taken to imply that such right of review can thereafter exist, or that such attempted reservation has any effect to make the remittitur other than absolute and unconditional." 46 The Supreme Court dismissed the plaintiff's writ of error on two grounds, the first echoing the ratio decidendi of Koenigsberger: the filing of the remittitur constituted a waiver by the plaintiff of his right to litigate the damage issue further. ${ }^{47}$ The second stated basis for the decision was procedural in nature. The Court characterized the remittitur as being a condition precedent to the judgment from which the plaintiff was appealing. Plamtiff's contest of the remittitur order in the appellate court removed the condition precedent and, consequently, the judgment itself, returning the proceedings in the lower court to an unappealable status. ${ }^{48}$

The Court's opmions in Koenigsberger and Woodworth fail to disclose the exact operation of the putative waiver entailed by a remittitur. The Supreme Court has recently held that the plaintiff, by filing a remittitur, is not waiving his right to appeal in the sense of compromising his claim against the defendant. ${ }^{49}$ In fact, the Court acknowledged that "[a]n order of remittitur is a judicial determination of recoverable damages; it is not an agreement among the parties involving inutual concessions." "50

Assuming that a plaintiff's acceptance of a remittitur is not a "waiver" or "compromise" with the defendant, the only party for whose benefit such a waiver might be enforced against the plaintiff is the court itself. The propriety of judicial enforcement of such a "waiver" is questionable. The court is in the position of taking away from the plaintiff a jury verdict, presenting him with the choice between a new trial and a reduction in damages, and binding him to his election of one of these two unpalatable alternatives. Assuming that the trial judge erred in ordering the remittitur, the plaintiff has no chance to preserve his valid verdict short of undergoing the uncertainty and expense of a new

45. Id. at 80-81.

46. Id. at 82 .

47. Id.

48. Id.

49. Banks v. Chicago Grain Trimmers Ass'n, 390 U.S. 459, $466-67$ (1968).

50. Id. at 467. 
trial and later, on appeal froin the judgment in that trial, having his origimal verdict reinstated.

Moreover, the validity of transferring the waiver argument from Koenigsberger, in which the remitting party apparently filed the remittitur without attempting at the same time to reserve his right to appeal, ${ }^{51}$ to Woodworth, in which the plaintiff made his reservations quite clear, ${ }^{52}$ is nowhere discussed in Woodworth. At least in those cases in which the plaintiff has not yet accepted the fruits of his judgment, ${ }^{53}$ and has signified his protest of the remittitur order, it hardly seems inequitable to allow him to appeal the court's action in forcing him to the choice of a new trial or a reduction in damages. ${ }^{54}$

The second arguinent against the "under protesi" rule advanced by the Supreme Court in Woodworth v. Chesbrough is the procedural one that judgment entered pursuant to a remittitur constitutes a judgment entered upon a condition precedent, and that, by withdrawing his consent to the remittitur, a plaintiff vitiates the very judgment from which he is attempting to appeal, and so has no ground upon which to assert appellate jurisdiction. ${ }^{55}$ Although the internal consistency of this argument is unassailable, its artificiality renders it susceptible to a rather simple answer. In the Fifth Circuit cases, that solution hes in the "under protes $t$ " requirement itself. Since the condition precedent is understood as the plaintiff's acceptance of the remittitur "under protest," i.e., with reservation of a right to appeal, a subsequent appeal will not breach the condition, and the judgment will stand.

The fundamental thrust of the Supreme Court's objection to the "under protest" procedure seems to be based not upon the technical "waiver" and "condition precedent" analyses undertaken in Woodworth; but rather upon an approbatory view of the nature and effect of a remittitur. According to this view, the remittitur order constitutes a judicial "favor" to the plaintiff to help him avoid a new trial, culminat-

51. No indication appears from the report that the plaintiff in Koenigsberger explicitly indicated that his acceptance of the remittitur was "under protest." If his "protest" was limited to taking exceptions and suing out a writ of error, it would seem that Koenigsberger's conduct would not allow him to appeal from judgment entered pursuant to his remittitur, even under current Fifth Circuit practice. See Movible Offshore Co. v. Ousley, 346 F.2d 870, 875 (5th Cir. 1965).

52. See 244 U.S. at 80-81.

53. Compare Woodworth v. Chesbrough, 244 U.S. 79, 80-81 (1917), with Lewis v. Wilson, 151 U.S. 551, 555 (1894).

54. Although at first glance the equities of the situation might appear in a different light to the defendant, it is not at all clear that defendants would, on balance, suffer from the introduction of the "under protest" rule. See text accompanying notes 75-78 infra.

55. 244 U.S. at 82. 
ing in a judgment for the plaintiff equivalent to the verdict of a "reasonable" jury, from which, under traditional procedure, he may not appeal. ${ }^{56}$

A change in the Court's attitude toward remittiturs can be perceived, however, in decisions subsequent to Koenigsberger and Woodworth. This shift in attitucle is most clearly revealed in Dimick $v$. Schiedt. ${ }^{57}$ Dimick itself decided that additurs would not be allowed in the federal courts, on the ground that their use would be repugnant to the seventh amendment. ${ }^{58}$ The remittitur practice, not before the Court in Dimick, was given what Professors Wright and Miller have termed a "grudging approval,"59 resting, it would seem, chiefly on the ground of stare decisis:00 remittiturs have been utilized in the federal courts simce $1822,{ }^{61}$ while additur is a device of more recent origin. ${ }^{62}$

Further grounds for distinction between additur and remittitur set out in Dimick were the existence of some common law precedent for remittiturs, ${ }^{03}$ and the fact that, while an order of remittitur is merely the "lopping off [of] an excrescence" by the court, ${ }^{44}$ an additur is a "bald

56. See, c.g., Gunn v. University Comm. to End the War in Viet Nam, 399 U.S. 383, 390 n.5 (1970); Public Serv. Comm'n v. Brashear Freight Limes, Inc., 306 U.S. 204, 206 (1939) (decision based upon statutory appellate jurisdiction of Supreme Court from decrees of three-judge district courts, formerly 28 U.S.C. \& 380 , presently codified as amended at 28 U.S.C. \& 1253 (1970)). But see Embry v. Palmer, 107 U.S. 3, 8 (1882) (victorious plaintiff held allowed to appeal from decree limiting execution on his judgment). The Supreme Court's enthusiasm for remittiturs at the time of Koenigsberger is perhaps exemplified by the fact that on at least three occasions roughly contemporaneous with Koenigsberger, the Court itself ordered remittiturs as conditions of affirmance of lower court judgments. Hansen v. Boyd, 161 U.S. 397, 411-12 (1896); Washington \& G. R.R. v. Harmon's Adm'r, 147 U.S. 571, 590 (1893); Phillips \& Colby Constr. Co. v. Seymour, 91 U.S. 646, 656 (1875).

57. 293 U.S. 474 (1935).

58. Id. at 486-87.

59. 11 C. WRTGHT \& A. MHLER, supra note 4, $\$ 2816$, at 107.

60. 293 U.S. at $484-85$.

61. The use of remittiturs in the federal courts may be traced back to the decision of Blunt v. Little, 3 F. Cas. 760 (No. 1578) (C.C.D. Mass. 1822). In Blunt, Justice Story, sitting in his capacity as Circuit Justice, based his power to order a remittitur sheerly on the judge's traditional authority to order a new trial on the ground of excessive damages. Despite the somewhat attenuated character of such reasoning, Blunt was cited with great frequency as authority for the remittitur power throughout the nimeteenth century, with very little attendant discussion of the underlying rationale for the remittitur power, or of any way by which the remittitur might be reconciled with the seventh ameudment's mandate that no jury finding "shall be otherwise re-examined in any Court of the United States, than according to the rules of the common law." See, e.g., Arkansas Valley Land \& Cattle Co. v. Mann, 130 U.S. 69, 73 (1889); Northern Pac. RR. v. Herbert, 116 U.S. $642,646-47$ (1886).

62. 293 U.S. at $484-85$.

63. Id. at $487-88$.

64. Id. at 486. 
addition of something which in no sense can be said to be included in the verdict." $"$ As to the first of these distinctions, however, the Court stated in Dimick itself that the common law precedent for remittiturs consists merely of "the practice of some of the English judges-a practice which has been condemned as opposed to the principles of the common law by every reasoned Enghish decision, both before and after the adoption of the Federal Constitution, which we have been able to find." validity of this distinction. The second ground, that a remittitur inerely reduces damages to a "lesser imcluded amount" of the jury's finding ${ }^{67}$ is also open to dispute. The jury, in reaching its verdict for a certain sum, has presumably rejected all other amounts in arriving at that verdict; therefore, choosing a rejected amount that is higher than the actual verdict would seem no greater an intrusion into the jury's domain than selecting a rejected amount lower than that verdict. ${ }^{68}$ The distinction between remittitur and additur may thus fairly be said to he chiefly in the inertial, stare decisis effects of the long history of the remittitur in federal courts. This conclusion finds support in the Court's statement in Dimick that "[i]n the light reflected by the foregoing review of the Enghish decisions and commentators, it, therefore, inay be that if the question of remittitur were now before us for the first time, it would be decided otherwise." 69

More recently, the Court has accepted the proposition that "[a]n order of remittitur is a judicial determination of recoverable damages "70 Since this determination reduces the award granted to plaintiff by the jury, it can logically be regarded as sufficiently adverse to sustain an appeal. Such is the view espoused by the Fifth Circuit. ${ }^{11}$ If this view

65. Id.

66. Id. at 484 .

67. Id. at 486 .

68. Carlin, Remittiturs and Additurs, 49 W. VA. L.Q. 1, 18 (1942). But see James, Remedies for Excessiveness or Inadequacy of Verdicts: New Trial on Some or All Issues, Remittitur and Additur, 1 DUQUESNE L. Rev. 143, 154-55 (1963).

69. 293 U.S. at 484.

70. Banks v. Chicago Grain Trimmers Ass'n, 390 U.S. 459, 467 (1968).

71. In Delta Eng'r Co. v. Scott, 322 F.2d 11 (5th Cir. 1963), cert. denied, 377 U.S. 905 (1964), the first Fifth Circuit case to apply the "under protest" rule, the court stated that "[i]t would be a strange rule that would keep a plaintiff from challenging the legal correctness of any action having such portentous consequences." 322 F.2d at 15. In a later "under protest" decision, the Fifth Circuit reaffirmed the view expressed in Delta Engineering, holding that the plaintiff, who was refused an appeal from the remittitur order itself on the ground that the order was merely interlocutory, had suffered a "sufficiently adverse adjudication" to be allowed to appeal from the judgment entered pursuant to her protested remittitur. Steinberg v. Indemnity Ins. Co. of North America, 364 F.2d 266, 268 (5th Cir. 1966). 
is correct, as Dimick indicates, ${ }^{72}$ the apparent foundation of the Court's decision in Woodworth has crumbled.

The "under protest" rule inay, in fact, present itself as a procedure by which the judge's virtually untrammeled discretion in controlling jury verdicts, disapproved in Dimick, can be limited. The practice of allowing a remitting party to obtain immediate review of the action of the trial judge in forcing hin to surrender a part of his jury verdict is, on balance, supportive of the jury autonoiny sought to be preserved by the seventh amendment. The Fifth Circuit's version of the "under protest" rule allows the appellate court two options in reviewing the trial judge's remittitur order: the court nay affirm, finding the remittitur to have been proper; alternatively, the court may find error in the order, and direct that judgment be entered on the origmal verdict. ${ }^{73}$ The operational effect of the rule is thus simply to render immediately reviewable by an appellate court the trial judge's capacity to deprive plaintiffs of their jury verdicts, and thereby to diminish the possible exercise of judicial supervision of juries. In short, the tension identified by the Court in Dimick, the threat to jury autonony posed by the remittitur practice on the one hand and the disruption of settled case law that would be entailed in holding remittiturs unconstitutional on the other, has created an ambivalence in the Court's thinking on the remittitur issue. Against this background, the "under protest" rule should commend itself as a means of curbing the ability of trial judges to "reexamine" jury verdicts while domg hittle violence to established case law.

The precedential value of Koenigsberger and Woodworth in cases involving remittiturs ordered by trial judges is further diminished by the fact that both cases involved remittiturs ordered by appellate tribunals. ${ }^{74}$ With the sensitivity to the seventh amendinent ramifications of remittiturs voiced in Dimick, the groundwork has been laid for the limitation of Koenigsberger and Woodworth to their own facts, i.e., appellate remittiturs, and the adoption of the "under protest" rule in cases involv-

72. See 293 U.S. at 484-85 and text accompanying notes 57-69 supra.

73. Wiggs v. Courshon, 485 F.2d 1281, 1283 (5th Cir. 1973). The Second Circuit in Reinertsen v. George W. Rogers Constr. Corp., No. 564 (2d Cir., July 3, 1975), see note 10 supra, postulated a third possibility-the ordering of a reduced remittitur by the appellate court. As the court points out, in such an instance "plaintiff's consent to the larger remittitur should certainly cover the smaller." Id. at 4652. Moreover, such a situation assumes not only the presence of an irrational jury but an abnse of discretion by the trial judge. The likelihood of these two factors occurring in the same trial cannot be great.

74. This distinction was pointed out with respect to Woodworth in Thomas v. E. J. Korvette, Inc., 329 F. Supp. 1163, 1171 (E.D. Pa. 1971), rev'd on other grounds, 476 F.2d 471 (3d Cir. 1973). 
ing trial court remittiturs. The courts of appeals would thus seem to be free, as the Fifth Circuit has apparently deemed itself to be, to formulate their own policies as to application or nonapplication of the "under protest" rule.

\section{The Effects of the "Under Protest" Rule ON JUDICIAL ECONOMY}

Since the courts of appeals are unconstrained by either state practice or direct federal precedent in their choice as to application of the "under protest" rule, soine notice may justifiably be taken of the effect of the introduction of that procedure upon the workloads of the district and appellate courts. Although it is beyond the scope of this Note to undertake any detailed analysis of the problem, some preliminary observations may be offered.

The optimal scenario for the "under protest" rule would be one in which a jury correctly delivers a verdict for plaintiff, and the trial judge, believing the verdict to be excessive, abuses his discretion by ordering a prohibitive remittitur as a condition to his refusing a defendant's motion for a new trial. The plaintiff confronted with this situation has but two options under the traditional view, no inatter how flagrant he may believe the trial judge's abuse of discretion to have been. Those options are to accept judgment for a mere fraction of his origmal verdict, or to submit to a new trial, with the possibility that he will receive a lower damage award in that second trial, and the certainty that he will be put through a great deal more trouble and expense. Assuming sufficient resources on the plaintiff's part, or sufficient faith in the eventual outcome of the litigation, the plaintiff will opt for the new trial. The new trial will, of course, necessitate the empaneling of a new jury and the expenditure of considerable judicial time in the district court.

Under the Fifth Circuit's rule, the plaintiff confronted with an unreasonable remittitur order may simply file the remittitur "under protest" and appeal, hoping for a reversal in the court of appeals. Should the appellate tribunal reverse, the litigation will be at an end, and the plaintiff will have been returned to the status quo ante the remittitur order. Should the court of appeals affirm, the litigation will be at an end nonetheless, plaintiff having had an appellate hearing on the alleged error of the trial judge. The "under protest" rule will, under this scenario, have saved considerable time and expense for the litigants and for the district court, arguably at the expense of soine time in the appellate court.

Any problems with the "under protest" rule lie, therefore, chiefly 
in the effect of shifting an additional caseload to the courts of appeals. This additional caseload would consist chiefly of unmeritorious appeals, since many unreasonable remittitur orders would come before the appellate courts for review at the conclusion of the second trial even under the traditional rule. Although there have been indications that the appellate courts are considerably more overburdened than are the federal district courts, ${ }^{35}$ the shift in caseload to the appellate courts may cause fewer problems than one might suppose. An appellate court, unlike a trial court called upon for a trial de novo, may dispose of an unmeritorious appeal by a per curiam opinion or no opinion at all, with relatively little expenditure of judicial time. ${ }^{76}$ Thus, the net effect of the additional caseload might well be quite negligible.

Moreover, although once again conclusive data is lacking, the frequency with which remittitur orders will require full-dress appellate consideration should be limited by the relative simiplicity of the issues involved, and the rather heavy burden whicl must be carried by the remitting plaintiff on appeal. As applied in the Fifth Circuit, the "under protest" rule requires that the appellant show that the trial judge abused his discretion in ordering the remittitur by requiring remission "of a sum which would reduce the verdict below the maximum award which is reasonably supported by the evidence." ${ }^{\text {T }}$ The relatively clear-cut nature of this standard should reduce considerably the burden of the appellate court in dealing with appeals from judgments rendered pursuant to "protested" remittiturs.

Further consideration of the effect of adoption of the "under protest" rule from the standpoint of judicial economy must await statistical study. ${ }^{78}$ The brief overview of the problem presented here would seem to indicate, however, that the increased burden on appellate courts might well be more than balanced by the benefit to litigants in obtaining speedy review of remittitur orders, and to the district courts in avoiding a number of new trials.

75. See generally Carrington, Crowded Dockets and the Courts of Appeals: The Threat to the Function of Review and the National Law, 82 HARv. L. REv. 542 (1969); Commission on Revision of the Federal Court Appellate System, The Geographical Boundaries of the Several Judicial Circuits: Recommendations for Change, 62 F.R.D. 223 (1973); Proceedings of the A.B.A. 93rd Annual Meeting, Improving Procedures in the Decisional Process, 52 F.R.D. 51 (1970). It is interesting to note that the secondmentioned source hists the Fifth Circuit as the most overburdened circuit of all. 62 F.R.D. at 230.

76. Carrington, supra note 75 , at 559.

77. Bonura v. Sea Land Serv., Inc., 505 F.2d 665, 669 (5th Cir. 1974).

78. A call for such study was issued by the Second Circuit in Reinertsen v. George W. Rogers Constr. Corp., No. 564, att 4654 (2d Cir., July 3, 1975). 


\section{CONCLUSION}

This Note has offered an analysis of the considerations underlying the appealability of judgments entered pursuant to remittiturs in the federal courts. The conclusion to be drawn from the cases would seem to be that the federal courts of appeals are free, from the standpoint of both state practice and Umited States Supreme Court precedents, to shape their own procedures as to appeals by remitting parties. The decision as to whether other federal circuits should follow the Fifth Circuit in applying an "under protest" rule becomes, therefore, a relatively unfettered policy choice, governed at least in part by the goals of naximizing judicial economy and balancing the rights of plaintiffs and defendants in civil actions.

Although organized statistical study must precede any final decision on the effects of the "under protest" rule on judicial economy, there would seem to be hittle reason to fear that introduction of the "under protest" rule would cause an intolerable increase in appellate caseload. Any increase that did occur would, in all likelihood, be balanced by the reduction in the number of new trials in the district courts. In instances involving flagrant abuses of discretion by trial judges in ordering remittiturs, the "under protest" rule would unquestionably save time and expense for both plaintiffs and defendants; the savings to defendants in these cases might, however, be offset by some increase in the number of frivolous appeals that might result from abandonment of the traditional rule. Such conclusions are, however, quite speculative in the absence of statistical data.

What seems certain is that the seventh amendment ramifications of the remittitur process render the "under protest" rule a desirable one, introducing as it does a ineans by which trial judges' "reexaminations"of jury verdicts may be readily reviewed. In the absence of any data indicating a pronounced detrimental effect of the rule on appellate caseload, the "under protest" rule would seein on balance to be a salutary one for the federal courts to adopt. 